DOI: https://doi.org/10.32839/2304-5809/2021-6-94-38

УДК 821.161 .2

Змінчак H.M.

Одеська державна академія будівництва та архітектури

\title{
ПРОЗА ВАЛЕНТИНА ТАРНАВСЬКОГО КРІЗЬ ПРИЗМУ ПОНЯТЬ СИМВОЛ ТА СИМУЛЯКР
}

\begin{abstract}
Анотація. У статті подано аналіз ролі символів та симулякрів у системі поетики прози Валентина Тарнавського. Відзначено, що художній світ романів митця репрезентуе простір глобальної симуляції, в якому реальне змістовне буття замішуеться штучно створеним фантомом. Образи героїв творів, до того ж як протагоністи, так і антагоністи, так само видаються симулякрами. Радянська дійсність, що е тлом романів прозаїка, $є$ вдячним грунтом для художнього зображення симулятивної реальності. Дослідження специфіки символів та симулякрів у прозі письменника, який увійшов у літературний процес в період перехідності культури (кінець XX століття), дозволяе увиразнити поетикальні властивості та аксіологічні аспекти його творчості.
\end{abstract}

Ключові слова: символ, симулякр, інтелектуальний роман, мандрівний сюжет, постмодернізм.

Zminchak Natalia

Odessa State Academy of Civil Engineering and Architecture

\section{VALENTYN TARNAVSKY'S PROSE UNDERSTANDING THROUGH THE PRISM OF SYMBOL AND SIMULACRUM}

Summary. Valentyn Tarnavsky is a prominent representative of Ukrainian literature of the 1980s. The writer's artistic achievements are insufficiently covered in literary studies. To present the originality of V. Tarnavsky's individual style, it is necessary to analyze novels that combine the features of mass and elite culture. This fact convincingly demonstrates the ability to take into account the aesthetic tastes and psychological characteristics of the reader. In Valentyn Tarnavsky`s artistic system the concepts of symbol and simulacrum are present simultaneously. In his early novel "Urban motives" there is interpretation of the "communistic society» with it's desire of material goods, which is based on the simulation of a happy life effect. The essential self-determination of the individual is replaced by simulated pseudo-similarity. With the transition to the large genre forms represented by novels «The Empty Pedestal» and «Matriopol» communistic ideas-simulacra are most clearly manifested which testifies to the politicization, which is especially felt in social art. The article presents an analysis of symbols and simulacra in the system of poetics of prose by Valentyn Tarnavsky. It is noted that the artistic world of his novels represents the space of global simulation, in which the real meaningful being is replaced by an artificially created phantom. Images of the heroes of the works, in addition to both the protagonists and antagonists, also appear as simulacrum. Soviet reality, which is the background of the prose writer's works, is a grateful ground for the artistic depiction of simulated reality. We find the disorder of the material and the spiritual life's philosophical interpretation in Valentyn Tarnavsky's novels «Matriopol» and «The Empty Pedestal», which focus the recipient's view on the problem of meaningful life, instead of it's imitation. The study of the specifics of symbols and simulacra in the prose of the writer, who entered the literary process during the transition of culture (late twentieth century), allows to express the poetic properties and axiological aspects of his works.

Keywords: symbol, simulacrum, intellectual novel, wandering plot, postmodernism.

$\Pi$ остановка проблеми. Як поняття символ, так і симулякр, маючи давню історію, опинились у центрі уваги літературознавців та культурологів на зламі століть, продемонструвавши кризу свідомості людини в перехідні етапи розвитку культури. Іван Фізер у своїй грунтовній роботі «Філософрія літератури» наводить таке міркування: «представники постмодерністської фрілософії критикували... концепцію раціонально доведено істини» [8, с. 132]. Література постмодерного періоду так само апелюе до ірраціонального пізнання буття, чим визначається вибір художніх засобів. У статті подано спробу осмислення ролі символів та симулякрів у прозі Валентина Тарнавського.

Аналіз останніх досліджень і публікацій. Корені терміна "симулякр» сягають античних джерел, він пов'язаний з ученням Платона про мімесис, у межах якого розглядаються категоpiї ейдос та ейдолон. Останню фрілософр характеризував як копію, котра не має оригіналу [5].
Саме поняття ейдолон, трансформуючись у симулякр, актуалізуеться у працях фрранцузьких фрілософрів XX століття Жоржа Батая, Жіля Дельоза, Жана Бодрійяра, котрі трактують його у різних аспектах, як категорію, що приходить на зміну символу.

Засновуючись на дефініції Й. В. Гете, вважаємо, що символ «...перетворює явище в ідею, ідею в образ і до того ж так, що ідея залишається в образі безкінечно дієвою і неосягненою. Навіть виражена всіма мовами, вона залишилась би все-таки невисловною» [2, с. 352]. Інакше кажучи, специфіка символа полягае у невичерпності смислів, він поглиблює художній текст, у той час коли симулякр жодного смислу не несе. Через те світ симуляції Ж. Бодріяр закономірно називає асимволічним світом [1, с. 173].

Ж. Дельоз вдається до зіставлення поняття «симулякр» із копією, стверджуючи: «Копія це образ наділений схожістю, тоді коли симулякр - образ позбавлений схожості» (Переклад 
мій. - Н.3.) [3, с. 334]. Філософр ілюструе природу симулякра прикладом з Катехізісу: згрішивши, людина, створена за Божою подобою, втратила їі, проте зберегла образ. Отож, ефрект подоби є зовнішнім, бо людина «відмовилась від морального існування на користь існування естетичного» (Переклад мій. - Н.3.) [3, с. 334]. Філософрське осмислення розладу матеріального й духовного знаходимо у літературі посмодернізму, що спрямовуе погляд реципієнта на проблематику осмисленого, змістовного побутування, замість його імітації.

Виділення не вирішених раніше частин загальної проблеми. Проза Валентина Тарнавського е об'єктом вивчення таких науковців, як: Аністратенко А., Даниленко В., Козачук Н., Саєнко В., Синицька Н. та інші. Проте деякі питання поетики митця залишаються білими плямами. Актуальність поданого дослідження зумовлена тим, що поняття симулякра у прозі Валентина Тарнавського ще не було досліджено у наукових розвідках.

Мета статті. Віднайти у прозі Валентина Тарнавського, головно у романах, смислові й поетикальні аспекти використання символів та симулякрів, що вписують письменника у контекст літератури постмодернізму.

Виклад основного матеріалу. У художній системі Валентина Тарнавського концепти символ і симулякр присутні одночасно. Уже в ранній його повісті «Міські мотиви» дається взнаки осмислення проблематики «суспільства споживання», 3 його бажанням накопичення матеріальних благ, в основі якого лежить едект симуляції щасливого життя: сутнісне самовизначення особистості заступає симулятивна псевдоподібність. 3 переходом до великих жанрових форм, репрезентованих романами «Порожній п'єдестал» та «Матріополь», найвиразніше оприявнюються комуністичні ідеї-симулякри, що свідчить про "політизованість (особливо відчутну в соц-арті), настільки невластиву західному постмодерну в цілому» (Переклад мій. - Н.3.) $[4$, c. 293]. Така характеристика випливає зі специфріки витоків українського постмодернізму, що виникає не після модернізму, а приходить на зміну соцреалізму, тому художній світ романів Валентина Тарнавського змодельовано за зразком радянського.

Так, героя роману «Матріополь» переміщено до віртуального світу острова шляхом застосування прийому «подвійної присутності»: впавши у марення у реальному світі, Ілля здійснив перехід в оніричний простір. Такий поетикальний хід передбачає насиченість прийомів інакомовлення, тому перед читачем стоїть завдання розпізнати значення символів, аби розкрити логіку автора.

Народжений спершу в уяві Ейдос, а згодом матеріалізований світ Матріополя ілюструє поняття гіперреальності - «симуляції чогось, що ніколи насправді не існувало» (Жан Бодріяр) - це «металевий світ, увесь напружений, але позбавлений чуттєвості» [1, с. 173]. Кожен його елемент, починаючи живописними пейзажами острова й закінчуючи красою правительки Ейдос, видався героєві роману - Іллі - холодним і неживим. Конструювання Матріополя за критеріями естетичності демонструє явище зникнення прекрас- ного, що в інронічному ключі виставляє Валентин Тарнавський, змішуючи високе і низьке у назвах «Храм для відправлення найбанальніших людських потреб», «золотий трон, себто унітаз».

Обличчя та тіло Ейдос становлять симулякр: «Ледь помітні рубці за вухами прикривало чорне, як воронове крило волосся, напнута шкіра обличчя, припудрена до алебастрової синяви, брови намальовані хімічним олівцем. Дивно було, що ця підмоложена голова увінчувала гладеньку дівочу шию, свіже лебедине тіло... Імпресіоністичний ефект. Вона могла видатися красунею тільки здалля» [6, с. 127]. Виказуючи прагнення до ідеалу калокагатії, привабливий каркас помножений на міфологізацію персони Ейдос, як наймудрішої та найсправедливішої, творить ілюзію, яка спонукає громадян острова-держави до ентузіастичного служіння своїй покровительщі. У їх сприйнятті бажане видається за дійсне, що пояснюеться поверховістю, відсутністю глибини вражень: «Калейдоскоп естетичних емоцій, почуттів, сприйняття, смаку закривається, залишаючи на поверхні лише нарцисичне споглядання, позбавлене онтологічної дистанції» (Переклад мій. - Н.3.) [4, с. 61-62].

В одному з основних локусів острова - інженерному центрі - працювали над проєктом створення надлюдини. «Всю тисячолітню історію мистецтво намагалося переробити людину, відсікти від неї все нице й потворне - жадібність, зажерливість, природні інстинкти, керувалося найблагороднішими намірами, прагнуло до ідеалу, створювало героїв, в яких втілювалися всі чесноти, - і в результаті цих неймовірних зусиль, високих поривів... замість боголюдей виходили нелюди, позбавлені земного і небесного, франатичні ніхто, привиди, монстри, свині, ляльки, зшиті білими нитками» [6, с. 215].

Семантична площина цього локусу Матріополя, як видається, поєднує у собі кілька смислів, перший 3 яких метафоричний: штучне створення людини в центрі подібне до насильницької уніфікаціï homo sovieticus; другий же не втрачає своєї гостроти і нині, коли людина прикладає закони краси і гармонії виключно до зовнішності, створюючи ідеальний образ себе. Невідповідність цьому образові змушуе постійно підганяти себе під загальноприйняті стандарти зовнішньої краси і показного успіху в соціальному плані, втягуючи в механізм споживацької машини. У цій гонитві губиться краса оригіналу, а тепло душі, що внутрішнім сяйвом освітлює обличчя, на вагах пріоритетів островитянок відходить на другий план. Та навіть серед такої тотальної одноманітності бувають винятки.

Лідія, яку Ілля зустрічає першою на острові, за логікою характеру не вміла брехати і бути байдужою до несправедливості. Будучи завжди відмінницею в роботі, вона отримувала нагороди за служіння Ейдос. Однак Лідія не мала змоги атестувати свої людські якості, бездоганна машина не знала, як діяти у надзвичайних ситуаціях, коли доводиться керуватись власним розумом, що свідчить про зникнення саморедлексії, як іманентної риси людини. Таким чином В. Тарнавський торкається проблеми наявності моральної інтуїції у особи, котра стоїть перед вибором між обов'язком і совістю. А стандартизо- 
ване життя на острові-державі не дає змоги виявити увесь потенціал особистості, реалізувати екзистенційну природу людської душі, приреченої вибирати і нести за це персональну відповідальність.

Герой іншого роману В. Тарнавського - «Порожній п'єдестал» - Унксов перебуває у постійному пошуку невловимої істини. У радянському суспільстві межі аутентичного та підробного були розмиті, маргінальне та центральне помінялись місцями.

Маючи можливість стати ученим, Унксов надає перевагу симуляції. Розкопавши стародавню скриню, що давала змогу симулювати наукову роботу інституту, штампуючи псевдоділові папери, герой закидає наукову діяльність. Інститут продовжуе фрункціонувати, тоді як сенс існування, його сутність давно знищено. I парадокс у тому, що таке функціонування анітрохи не страждає від цього, а навпаки, стає все більш досконалим.

Репрезентативним у цьому плані $є$ й епізод 3 пам'ятником, який Інокентію Вольфовичу мають намір створити за життя. Скульптор робить його у стилі «голого реалізму», відтак усі недоліки Унксова відбиті в монументі: «Інокентій Вольфович тільки кліпнув. Перед ним конав у агонії гіпсовий мрець, який бачив кінець світу. У зморшках відбилися нелюдські муки, сліпі очі нічого не розуміли, у розкритому роті завмер німий крик» [7, с. 224]. Отже, монумент постає як alter ego героя, як зримий образ справжнього Унксова: «...тріснула, розсідаючись, обшивка, відкриваючи таємницю, яку сховав у собі. Порожньо там було. Зміст перейшов у фрорму» [7, с. 424].

Після довгих мук творчості скульптор демонструе новий витвір науковцеві: пам'ятник «був у вигляді потужної бронзової спіралі, що угвинчувалась ракетою під самісіньку стелю, сяючи нестерпним блиском» [7, с. 378]. Унксову імпонує таке його зображення, після деяких вагань він впізнає себе в спіралі - цілеспрямованого, рішучого, який стрімко ввірвався в науковий процес і повністю присвятив себе науці на благо суспільства. Модифікована скульптура стає знаком симулящї, бо фальсифрікуе справжню суть його прообразу.

Ілюстрацією симулякрів другого порядку (за Бодріяром) у романі постає неабияка схожість підлеглих на свого керівника, вони мавпують його висловлювання, манери і міміку. Підіймаючись інститутом поверх за поверхом, зустрічаємо численних секретарів Унксова, схожих як один на свого володаря, у цьому і виявляеться відчуження від власного «Я», коли люди стають невиразними копіями тих, хто знаходиться вище на кар'єрних сходах.

Беззмістовним симулякрам, що претендують на символізм, протиставляються сакральні символи, покликані впорядкувати хаос постмодерного світу. В художній системі Тарнавського представлені здебільшого національні символи, що дозволяе без декларативності висловити свою політичну позицію.

Висновки і пропозиції. Аналіз прози Валентина Тарнавського у розрізі понять символа та симулякра опрявнюе багатопланову природу його творів. Проаналізувавши поетику романів Валентина Тарнавського, приходимо до висновку: радянська дійсність, відтворена у художньому світі прози митця, постає простором тотальної симулящії. Таким чином симулякр пов'язаний зі спектром онтологічних та аксіологічних проблем. До того ж симулякр відіграє жанротворчу роль у романі-антиутопії «Матріополь». Перспективними видаються подальші дослідження природи симулякра у прозі вісімдесятника Валентина Тарнавського у контексті як української, так і інших літератур періоду кінця ХХ століття.

\section{Список літератури:}

1. Бодріяр Ж. Симулякри і симуляція. Київ : Основи, 2004. 230 с.

2. Гете И.В. Избранные фрилософские произведения. Москва, 1964. 547 с.

3. Делёз Ж. Симулякр и античная философия. Логика смысла. Москва : Академический проект, 2011. С. $328-345$.

4. Маньковская Н.Б. Эстетика посмодернизма. СПб. : Алетейа, 2000. 347 с.

5. Пчелина О. Время символа и время симулякра. Вестник Московского государственного областного университета. Серия «Философбские науки». 2010. № 1. С. 113-117.

6. Тарнавський Валентин. Матріополь. Київ : Український письменник, 2003. 238 с.

7. Тарнавський В. Порожній п’едестал. Київ : Рад. письменник, 1990. 428 с.

8. Фізер І. Філософрія літератури. Київ : НаУКМА, Аграр Медіагруп, 2012. 217 с.

\section{References:}

1. Bodriiar Zh. (2004) Symuliakry i symuliatsiia [Simulacra and Simulation]. Kyiv: Osnovy. (in Ukrainian)

2. Hete Y.V. (1964) Yzbrannye fylosofskye proyzvedenyia [Selected Philosophical Works]. Moscow. (in Russian)

3. Delëz Zh. (2011) Symuliakr y antychnaia fylosofyia [The Simulacrum and Ancient Philosophy]. Lohyka smysla. [The Logic of Meaning]. Moscow: Akademycheskyi proekt, pp. 328-345.

4. Mankovskaia N.B. (2000) Estetyka posmodernyzma [Aestetics of Postmodernism]. SPb.: Aleteia. (in Russian)

5. Pchelyna O. (2010) Vremia symvola y vremia symuliakra [Time of Symbol and Time of Simulacrum]. Vestnyk Moskovskoho hosudarstvennoho oblastnoho unyversyteta [Bulletin of Moscow State Regional University], vol. 1, pp. 113-117.

6. Tarnavskyi V. (2003) Matriopol [Matriopol]. Kyiv: Ukrainskyi pysmennyk. (in Ukrainian)

7. Tarnavskyi V. (1990) Porozhnii piedestal [The Empty Pedestal]. Kyiv: Rad. pysmennyk. (in Ukrainian)

8. Fizer I. (2012) Filosofiia literatury [Philosophy of Literature]. Kyiv: NaUKMA, Ahrar Mediahrup. (in Ukrainian) 